DOI:

УДК 338.1

\title{
Ольга Карапетян,
}

кандидат економічних наук, дочент кафедри безпеки, правоохоронної діяльності та фінансових розслідувань Тернопільського національного економічного університету ORCID: http://orcid.org/0000-0002-8747-7631

\section{ІНСТИТУТ СУВЕРЕННИХ ФОНДІВ ДОБРОБУТУ: БЕЗПЕКОВІ АСПЕКТИ ТА ЕКОНОМІКО-ПРАВОВІ ЗАСАДИ}

Розглянуто діяльність найбільших суверенних фондів добробуту і проводено аналіз функиій, завдань та ризиків, пов'язаних з діяльністю суверенних фондів добробуту. Порушено питання мотивації таких фондів, їх значення для основних учасників фінансового ринку в контексті впливу на економічну безпеку. Аргументовано, щио на рубежі четвертої науково-технічної револючії необхідно звернути увагу на багаторічний досвід управління державними резервами для визначення основних тенденцій розвитку суверенних фондів. Крім того, окрему увагу приділено кількісному очінюванню впливу різноманіття економічних чинників на функціонування суверенних фондів. Окреслено опис основних тенденцій розвитку і проблем функціонування найбільших суверенних фондів світу. Акцентовано увагу на головних проблемах функціонування суверенних фондів та визначено основні ризики їхньої діяльності. Визначено організачійно-правові засади формування суверенних фондів добробуту та окреслено перспективні напрямки покращення їхньої діяльності.

Ключові слова: суверенні фонди добробуту, економічна безпека інвестиційна стратегія, бюджетна політика, ресурсні (сировинні) фонди, нересурсні фонди.

Бібл.: 6; рис.: 1; табл. 1.

Карапетян $\boldsymbol{O}$.

Институт суверенных фондов благополучия: безопасность аспекты и экономико-правовые основы.

Рассматрено деятельность крупнейших суверенных фондов благосостояния и проводится анализ функиий, задач и рисков, связанных с деятельностью суверенных фондов благосостояния. Затрагиваются вопросы мотивации таких фондов, их влияния на основных участников финансового рынка в контексте влияния на экономическую безопасность. Аргументировано, что на рубеже четвертой научно-технической революиии, необходимо обратить внимание на многолетний опыт управления государственными резервами для определения основных тенденций развития суверенных фондов. Кроме того, особое внимание было уделено количественной оченке влияния многообразия экономических факторов на функционирование суверенных фондов. В статье представлено описание основных тенденций развития и проблем функционирования крупнейших суверенных фондов мира. Акиентировано внимание на ключевых проблемах функиионирования суверенных фондов и определены основные риски их деятельности. Определены организационно-правовые основы формирования суверенных фондов благосостояния и намечены перспективные направления улучшения их деятельности.

Ключевые слова: суверенные фонды благосостояния, экономическая безопасность инвестиционная стратегия, бюджетная политика, ресурсные (сырьевые) фонды, нересурсных фонды

\section{Karapetian $\boldsymbol{O}$.}

Institute of sovereign welfare funds: safety aspects and economic and legal principles

The article looks at the activities of the largest sovereign wealth funds and analyzes the functions, tasks and risks associated with the activities of sovereign wealth funds. The questions of motivation of such funds, their influence on the main participants of the financial market in the context of impact on economic security are raised. It is argued that at the turn of the fourth scientific and technological revolution, it is necessary to pay attention to the long-standing experience of managing the state reserves in order to determine the main tendencies of development of sovereign funds. In addition, particular attention was paid to quantifying the impact of a variety of economic factors on the functioning of sovereign wealth funds. The article describes the main development trends and problems of functioning of the largest sovereign wealth funds in the world. Attention is paid to the key problems of functioning of sovereign wealth funds and the main risks of their activity are identified. The organizational and legal principles of the formation of sovereign wealth funds are defined and the perspective directions for improving their activities are outlined.

(С) Ольга Карапетян, 2020 
Карапетян О.

Інститут суверенних фондів добробуту: безпекові аспекти та економіко-правові засади

It is argued that at the turn of the fourth scientific and technological revolution, it is necessary to pay attention to the long-standing experience of managing the state reserves in order to determine the main tendencies of development of sovereign funds. In addition, particular attention was paid to quantifying the impact of a variety of economic factors on the functioning of sovereign wealth funds. The article describes the main development trends and problems of functioning of the largest sovereign wealth funds in the world. Attention is paid to the key problems of functioning of sovereign wealth funds and the main risks of their activity are identified. The organizational and legal principles of the formation of sovereign wealth funds are defined and the perspective directions for improving their activities are outlined.

Keywords: sovereign wealth funds, economic security investment strategy, budgetary policy, resource (commodity) funds, non-resource funds.

Постановка проблеми. На сучасному етапі розвитку глобальної економіки існує безліч цілей створення суверенних фондів добробуту (СФД), зокрема досягнення сталого економічного зростання, забезпечення стабільного надходження інвестицій, збільшення державних резервів. Питаннями, пов язаними 3 регулюванням діяльності суверенних фондів, займається кілька спеціалізованих установ: Міжнародний форум суверенних фондів добробуту, Інститут суверенних фондів і Центр вивчення суверенних фондів, які зібрали грунтовні бази даних про діяльність цих фондів, що спільно з річними звітами самих фондів становили емпіричну базу нашої наукової розвідки.

Аналіз останніх досліджень і публікацій. Теоретична основа формування суверенних фондів розкрита в багатьох наукових працях, зокрема у фундаментальних напрацюваннях МВФ, дослідженнях центральних банків, окремих роботах таких дослідників, як Дж. О’Нілл (О’Neill, J.), Е.Ф. Нільсон (Nielseon, Erik F.), П. Бахаж (Bahaj, P.) Е. Монк (Monk, А.), Дж. Хугей (Houget, G.), Дж. Нюжі (Nugee, J.), Е. Труман (Truman, Е.), К. Лінабург (Linaburg, С.), М. Мадуел (Maduell, М.) та ін.

Незважаючи на велику кількість проведених досліджень, єдиної точки зору щодо оцінювання діяльності суверенних фондів добробуту так і не сформовано. 3 огляду на фрагментарний підхід до аналізу діяльності фондів у різні періоди оцінювання впливу суверенних фондів на економіку діаметрально змінювалася.

Мета статті - оцінити масштаби впливу діяльності суверенних фондів на світовий фінансовий ринок і на національні компанії різних країн, а також розширити теоретичні та методологічні уявлення про формування та використання суверенних фондів добробуту через призму світового досвіду.

Виклад основного матеріалу дослідження. Сутність інституту суверенних фондів виявляється через його публічно-правову природу та інвестиційний характер діяльності. Саме назване поєднання визначає особливості правового статусу суверенних фондів, які можуть бути розкриті через наступні ознаки.

По-перше, необхідно вказати на відособленість і приналежність державі активів суверенних фондів незалежно від їхньої організаційно-правової форми. Суверенні фонди завжди створюються і фінансуються державою, тому вони і називаються суверенними. Фінансові ресурси суверенного фонду можуть бути безпосередньо вбудовані в бюджетну систему держави. Незалежно від структури власності фонду його майно завжди є відокремленим. Водночас найменування «фонд» не вказує на організаційно-правову форму суверенного фонду. Так, суверенний фонд Республіки Казахстан - це юридична особа у формі акціонерного товариства «Фонд національного добробуту Самрук-Казина».

Власниками суверенних фондів зазвичай є центральний уряд або адміністрації регіонів. Вони можуть володіти коштами фонду безпосередньо або через частку в керівній компанії. Водночас суверенний фонд може управлятися як безпосередньо державою, так і непрямим чином.

По-друге, важливою ознакою $є$ їхнє формування і подальше інвестування ресурсів 3 метою вирішення завдань публічного характеру, незважаючи на те, що суверенні фонди не є благодійними організаціями і прагнуть до отримання прибутку [1].

Основною метою суверенного фонду вважають мобілізацію й акумуляцію його активів, тому що тільки збільшуючи свою ресурсну базу, суверенний фонд зможе реалізувати покладені на нього державою завдання щодо фінансування суспільно значущих проєктів. У зв>язку з цим варто зазначити, що більшість інвестицій, що здійснюються суверенних фондами, в т. ч. бюджетного характеру, за своєю правовою природою відповідають діяльності класичних інвестиційних фондів, проте в подальшому кошти суверенного фонду можуть бути використані для вирішення поставлених перед ним завдань (наприклад, фінансування дефіциту бюджету). Наприклад, ірландський суверенний фонд, який інвестує в розвиток інфраструктури, шкіл і доріг, агропромислового сектору, в інноваційну діяльність суб〉єктів малого та середнього підприємництва, згідно 3 положеннями ірландського законодавства, керується принципом «подвійної прибутку», відповідно до якого кожен інвестиційний проєкт повинен приносити не тільки прибуток, а й має позитивно впливати на економіку Ірландії [1]. 
За призначенням суверенні фонди можна поділити на:

- стабілізаційні, які передбачають використання коштів фонду в періоди кризи;

- ощадні, що займаються перерозподілом надходжень на користь майбутніх поколінь;

- інвестиційні; фонди стратегічного розвитку, діяльність яких спрямована на стимулювання галузей національної економіки, формування джерел «довгих грошей» і компенсацію нестабільності бюджетних доходів [2].

Суверенні фонди можуть виконувати функції інститутів розвитку (Суверенний фонд Франції, або Суверенний фонд Казахстану). Вони також можуть додатково фінансувати такі інститути. У загальному контексті суверенні фонди можна згрупувати за джерелами наповнення на ресурсні та нересурсні. Ресурсні фонди мають на меті перерозподіляти кошти, отримані від високоприбуткових вичерпних ресурсів, в більш диверсифіковані фінансові активи. Діяльність нересурсних фондів спрямована на поглинання профіциту бюджету для акумулювання додаткових резервів. За станом на 2016 р. за оцінкою Sovereign Wealth Fund Institute, існує 81 суверенний фонд в 51-й країні (з них 31 - «нафтові»). На рис. 1 представлені країни за співвідношенням обсягу активів під управлінням СФД.

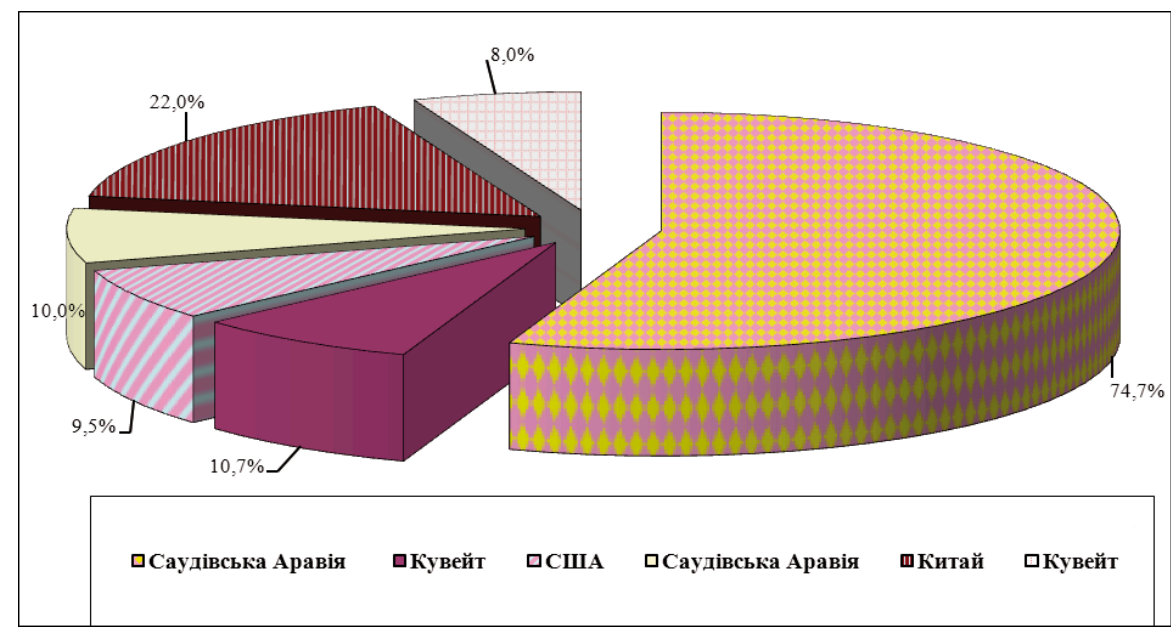

Рис. 1. Питома вага активів найбільших суверенних фондів у світових активах суверенних фондів добробуту (авторська розробка на основі [2])

Більшу частину з них становлять ресурсні фонди: на них припадає $61 \%$ всіх світових активів суверенних фондів. Серед нересурсних фондів особливо виділяються китайські, які керують $22 \%$ світових активів суверенних фондів і мають 72\% всіх активів нересурсних фондів. Якщо розглядати діяльність суверенних фондів більш детально, то варто відзначити їхнє різноманіття.

Всі фонди відрізняються один від одного за системою наповнення, можливими витратами, відкритістю інвестиційної політики та їі напрямками [3]. Причина активізації інтересу до цього виду державних заощаджень в різкому збільшенні обсягу ресурсів СФД. У 2017 р. сукупна величина активів досягла 7,2 трлн дол. США, що можна порівняти із сукупним обсягом світових золотовалютних авуарів, і становить трохи більше $10 \%$ капіталізації світового фондового ринку. Кількість суверенних фондів постійно збільшується. До 1990 р. було сформовано 16 фондів СФД, ще 20 створено з 1990 по 2005 рр. і 42 фонди - з 2005 до 2015 р. в 26-ти нових країнах. За останні 20 років капіталізація цих фондів збільшилася багаторазово: 500 млрд дол. США. Також варто зазначити, що суверенні фонди почали брати все більш активну участь в інвестиціях. В середньому в активах фондів 35-40\% становлять облігації, 50-55\% - акції, і 8-10\% - альтернативні інвестиційні продукти, такі як готівкова ліквідність, нерухомість і т. д. [4]. Пенсійні, інвестиційні та страхові фонди мають аналогічну аллокацію ресурсів.

Щодо діяльності суверенних фондів та їхнього впливу на решту світу дослідники часто вияаляють такі проблеми:

1. Відсутність прозорості в звітності фондів. Найчастіше фонди не публікують повну або хоча б часткову фінансову звітність, а також не розкривають правил розподілу і накопичення активів фонду. Через це важко визначення обсягів фонду, його інвестиційної політики, використовуваних інструментів і навіть географічного положення інвестицій. Оскільки суверенні фонди є державними установами, вони можуть керуватися неринковими мотивами і становити загрозу національним стратегічним установам іншої країни [4]. Уряди, наприклад, можуть використовувати СФД з метою контролю над компаніями в будь-яких важливих галузях іншої країни з метою сприяння їх власної політичної програми або можуть загрожувати національній безпеці іншої країни. 
Карапетян О.

Інститут суверенних фондів добробуту: безпекові аспекти та економіко-правові засади

2. Загроза ринкової стабільності. Наявні побоювання, що суверенні фонди, скупивши державні боргові цінні папери, через політичні чинники можуть швидко продати ці активи, щоб дисбалансувати фінансовий ринок.

У 2008 р. найбільші суверенні фонди створили незалежне професійне объєднання - Міжнародний форум суверенних фондів (далі - Форум), який займається питаннями збору та надання статистики щодо діяльності фондів, і в рамках якого публікуються численні доповіді, присвячені їхній діяльності. На базі цього Форуму було сформовано добровільно прийняті принципи («Принципи Сантьяго») [5]. У цьому документі передбачається, що країнам доцільно публікувати детальну звітність своїх суверенних фондів, у т. ч. правила наповнення $\mathrm{i}$ розподілу отриманого прибутку. Також вони повинні проводити щорічну перевірку аудиторських агентств, а в разі інвестування в іншу країну - попереджати відповідні органи. Незважаючи на те, що принципи добровільні і не в повному обсязі виконуються навіть тими учасниками Форуму, які під ними підписалися, це був значний крок у посиленні прозорості та дисциплінованості діяльності суверенних фондів. Щодо фінансової безпеки, то навіть до створення «Принципів Сантьяго» суверенні фонди завжди знаходилися під пильною увагою. Суверенні фонди добробуту, аналогічно як і звичайні інвестори, залежні від біржового регулювання. Так, придбання СФД акцій компаній вище певних порогових значень (5\% в США, $10 \%$ в СС), як правило, пов〉язане з вимогою до СФД повідомити про свою частку регулятору цінних паперів [6]. Певні інвестиції СФД, зокрема у фінансових установах (таких як банки і страхові компанії), підлягають особливим законодавчим обмеженням. Крім фінансового сектору, до галузей промисловості, які вважаються стратегічно важливими або мають соціальне значення (наприклад, енергетика, засоби масової інформації і телекомунікацій), часто застосовується законодавство, що регулює структуру ринку і поведінку інвесторів, які можуть бути застосовані до СФБ. Поряд з обмеженнями щодо конкретних галузей інвестиційна діяльність суверенних фондів може стати обґєктом пильної уваги в рамках антимонопольного законодавства. Щодо питання стабільності ринку, то в середньому $40 \%$ всіх активів суверенних фондів становлять державні боргові цінні папери, здебільшого американські казначейські облігації (treasuries).

Водночас простежується висока концентрація активів серед топ-15 найбільших фондів (табл. 1).

Крім вищесказаного, слід також розуміти, що більшості фондів мають законодавчо встановлений цільовий рівень прибутковості, який вони повинні підтримувати. Використання таких ризикових стратегій часто приводить до чистого збитку.

Суверенні фонди, на відміну від інших учасників ринку, керуються зовсім іншими мотивами. Першочерговим завданням СФД є стабілізація економічної ситуації і захист інтересів держави, що відображається на поведінці таких фондів і відповідно їхній вплив на світову економіку, а також на інтерпретації прийнятих фондами рішень.

Практично всі суверенні фонди спрямовують свої ресурси на підтримку національної економіки, особливо в кризові періоди.

Таблиия 1

Найбільші суверенні фонди добробуту за капіталізацією [2]

\begin{tabular}{|c|c|c|}
\hline Країна & Капіталізащія СФ, млрд. дол. США & Питома вага в сукупному обсяз \% \\
\hline Китай & 1534,7 & 22 \\
\hline ОАЕ & 1104,8 & 38 \\
\hline Норвегія & 824,9 & 50 \\
\hline Саудівська Аравія & 673,9 & 59 \\
\hline Кувейт & 592 & 68 \\
\hline Сінгапур & 537,6 & 75 \\
\hline Гонконг & 417,9 & 71 \\
\hline Катар & 213,46 & 84 \\
\hline США & 141,2 & 86 \\
\hline Казахстан & 139 & 88 \\
\hline Росія & 134 & 90 \\
\hline Австралія & 88 & 92 \\
\hline Південна Корея & 85 & 93 \\
\hline Лівія & 66 & 94 \\
\hline Іран & 62 & 95 \\
\hline Всього & 6995 & \\
\hline \hline
\end{tabular}


Для досягнення цих цілей СФД мають широкий набір заходів, починаючи від надання прямої допомоги конкретним організаціям (фінансовим і нефінансовим) як кредитор останньої інстанції або збільшення статутного капіталу стратегічно важливих підприємств, до більш загальних заходів, спрямованих на підтримку фондового ринку або курсу національної валюти. Прикладом служить криза 2008 р., під час якої банки потрапили в пастку ліквідності, коли скорочення процентних ставок і вливання додаткової ліквідності з боку центральних банків виявилося недостатньо для відновлення фінансової системи. У цей період майже $40 \%$ всіх угод СФД були спрямовані на допомогу національній економіці [3]. У періоди криз власний капітал банків різко стискається внаслідок знецінення активів, а зобов'язання залишаються незмінними. Невизначеність щодо вартості активів банків і перспектив відновлення відлякує інвесторів, і в цей момент інвестиції суверенних фондів особливо ефективні. СФД мають можливість брати акціонерну участь у компаніях, мають величезний досвід управління активами i, на відміну від центральних банків, можуть легко забезпечити довгостроковий характер фінансування. Це дає їм перевагу порівняно 3 традиційними фондами і валютними резервами центральних банків [3].

Норвезький пенсійний фонд, який має суворі обмеження щодо розподілу коштів на користь державного бюджету, відійшов від звичних 4\% загальної капіталізації фонду, які за законом він може перераховувати до держбюджету, і в кризові роки збільшив фінансування. У Франції необхідність підтримки вітчизняних фірм у 2008 р. зумовила створення нового СФД - Стратегічного інвестиційного фонду (FSI) - для їх рекапіталізації. Цілі, висунуті президентом, полягали в захисті стратегічних французьких фірм від іноземних поглинань. FSI допомагає фірмам різних за обсягом (від невеликих сімейних підприємств до великих компаній, таких як Veolia). На своєму вебсайті FSI наполягає на тому, щоб робочу силу фірми наймали у Франції. Особливість французького фонду полягає в тому, що він інвестує тільки в національну економіку, що не вписується в класичне визначення суверенного фонду згідно з МВФ. Зовнішне інвестування керується тими самими мотивами, що і внутрішнє, тому, з точки зору ринкової ефективності, суверенні фонди можуть приймати не найбільш економічно виправдані рішення. Так, під час кризи 2008 р. багато суверенних фондів надавали фінансову допомогу великим іноземним банкам, захищаючи інтереси своїх вітчизняних компаній. За 2008 р. фонди акумулювали ліквідності на 42 млрд дол. США. Це, наприклад, становило 15,4\% капіталу Merrill Lynch; 11,8 - UBS; 10,6 - Citigroup; 10\% - Morgan Stanley [2].

Відомо безліч прикладів, коли фонди діють відповідно до класичних уявлень про економічну раціональність. Важливо зазначити, що ставлення до діяльності фондів змінюється залежно від економічних обставин. Наприклад, в Індонезії, яка постраждала під час Азіатської кризи, позитивно сприймалися iнвестиції від Temasek, що купила частки двох найбільших телекомунікаційних компаній. Однак згодом, коли економічна ситуація налагодилася, ставлення до цих інвестицій різко змінилося, і в 2007 р. антимонопольна комісія винесла рішення про причетність Temasek щодо створення антиконкурентних умов, i одну з компаній довелося продати. Суверенні фонди можуть також ставати объєктами тиску зі сторони уряду i лобістських груп. Емпіричні дані показують, що СФД чинять стабілізаційний вплив на корпорації. Вони $\epsilon$ великими джерелами довгострокових прямих інвестицій [6].

Висновки. 3 огляду на вищенаведене доцільно зазначити, що суверенні фонди добробуту - це державні інвестиційні компанії, які в своїй діяльності оперують різними фінансовими інструментами, здебільшого - цінними паперами, номінованими в іноземній валюті. Пріоритетом розвитку суверенного фонду є прямі інвестиції, які не перевищують $10 \%$ капіталізації активів компаній. Інвестиційна діяльність таких фондів суттєво відрізняється від дій інших учасників фінансового ринку. За характером інвестування суверенні фонди націлені на виконання стратегічно важливих завдань держави. Антагоністичне ставлення до діяльності іноземних суверенних фондів підсилює протекціонізм у ставленні не тільки до таких фондів, а й до усіх інших учасників ринку, що миттєво позначається на інвестиціях, а також може викликати ускладнення в різних галузях національної економіки. Варто додати, що в разі необхідності посилення фінансової безпеки держави простіше контролювати фінансових посередників (інвестиційні банки), ніж вводити обмеження на діяльність самих фондів. Суверенний фонд може бути урядовою структурою, але управлятися або приватними особами, або представниками центрального банку. Винятком $є$ присутність у раді директорів представників уряду, але навіть у цих випадках працівниками є приватні особи. Відмінність у системах законодавства держав, що володіють суверенними фондами, а також практика функціонування таких фондів ускладнюють вироблення єдиного підходу. Проте необхідність у створенні міжнародної системи правового регулювання, що попереджає можливість зловживання з боку суверенних фондів, але одночасно і не дає змоги їх дискримінувати, вимагає спробувати вивести універсальне юридичне визначення цього поняття. 


\section{Список використаних джерел}

1. Global Financial Stability. International Monetary Fund Report. 2017. URL : http://www.imf.org/external/ pubs/ft/gfsr/pdf/chap1.pdf (дата звернення: 20.09.2018).

2. Сайт міжнародної робочої групи суверенних фондів добробуту. URL : http://www.iwg-swf.org (дата звернення: 12.04.2018).

3. Дем'янчук Д. О. Фонди суверенного добробуту як антикризовий стабілізатор економіки (світовий досвід та перспективи функціонування в Україні). Науковий вісник Академії муніџипального управління. 2013. Вип. 1. С. 184-192.

4. Підгурська О. Сутність та етапи розвитку фондів суверенного добробуту. Ефективна економіка. 2012. № 10 .

5. Agaciro Development Fund. Santiago Principles Self-Assessment Report. URL : http://www.ifswf.org/ assessment/rwanda (дата звернення: 15.01.2019).

6. An Introduction To Sovereign Wealth Funds. URL : https://www.investopedia.com/articles/economics/ sovereign-wealth-fund.asp (дата звернення: 01.04.18).

\section{References}

1. Global Financial Stability International Monetary Fund Report (2018). Retrieved from http://www.imf.org/ external/pubs/ft/gfsr/pdf/chap1.pdf [in English]

2. Sait mignarodnoi robochoi grupy suverennuh fondiv www.iwg-swf.org. [website of the International Working Group on Sovereign Wealth Funds] Retrieved from http://www.iwg-swf.org [in Ukrainian].

3. Demianchyk D. (2013). Fondu suverennogo dobrobutu yak antukruzovuj stabilizator economiku svitovuj dosvid ta perspektuvu funkcionuvannia $\mathrm{v}$ Ukraini [Funds of sovereign welfare as anticrises stabilizator of economy (world experience and prospects of functioning are in Ukraine)]. Naukovuj visnuk Akademii municypalnogo upravlinnia - The Scientific announcer of Academy of municipal management: Series «ECONOMY» Producing 1. 2013, 184-192 [in Ukrainian].

4. Pidgurska, O. (2012). Sutnist ta etapu rozvutku fondiv suverennogo dobrobutu [Essence and stages of development of funds of sovereign welfare]. Efektyvna ekonomika - Effective economy. Retrieved from http:// www.economy. nayka.com.ua/?op=1\&z=1289\&p=1 [in Ukrainian].

5. Agaciro Development Fund. Santiago Principles Self-Assessment Report. Retrieved from http://www.ifswf. org/assessment/rwanda [in Ukrainian].

6. An Introduction To Sovereign Wealth Funds (2018). Retrieved from https://www.investopedia.com/articles/ economics/sovereign-wealth-fund.asp [in Ukrainian]. 